\title{
Risk factors for mortality in elderly patients who live in nursing homes: 8-year follow-up period
}

\author{
Yasar Kucukardali', Arzu Yalcin², Murat Hakan Terekeci ${ }^{3}$, Mehmet Akif Ozturk', \\ Betul Kucukardali ${ }^{5}$, Elif Cigdem Altunok ${ }^{6}$ \\ ${ }^{1}$ Professor, ${ }^{2}$ Assistant Professor, ${ }^{3}$ Associate Professor, Department of Internal Medicine, Medical Faculty of Yeditepe \\ University, Atasehir, Istanbul, Turkey, ${ }^{4}$ Internal Medicine Specialist, Department of Internal Medicine, Fatih Sultan Mehmet \\ Education and Research Hospital, Istanbul, Turkey, ${ }^{5}$ Psychologist, Department of Psychology, Acibadem Altunizade Hospital, \\ Altunizade, Istanbul, Turkey, ${ }^{6}$ Statistician, PhD, Department of Biostatistics and Medical Informatics, Medical Faculty of \\ Yeditepe University, Kayisdagi, Istanbul, Turkey
}

Background: In developed countries and our country, the ratio of the elderly to the total population is increasing due to the rise in worldwide medical care spendings and the medical workforce allocated for the treatment of the acute and chronic problems of the elderly. Aims and Objectives: The number of studies based on long-term observations of the risk factors that affect the survival and mortality rates of the elderly in nursing homes is quite rare. Currently, there are no studies concerning this issue in the country. The authors carried out an eight years prospective study to determine the risk factors for mortality in a private nursing home with a capacity of 150 beds located in Istanbul. Materials and Methods: From January 2007 to March 2015, we scanned the number of medications, comorbidities, nutritional status, age, mental score, number of falls and fractures, levels of hemoglobin, albumin, creatinine, and glucose parameters related with mortality in 612 patients admitted to the nursing home. Results: The median overall survival time was 34 months. A total of $240(39 \%)$ residents died within eight years, $44 \%$ within two years and $55 \%$ within three years. The evaluation results shothat $360(51 \%)$ of the 612 residents, were females and the mean age was $76.49( \pm 11.36)$ years. Hazard ratios of the related parameters that related to mortality were respectively 1,3 for age, 1,5 for BMI less than $20 \mathrm{~kg} / \mathrm{m} 2,4,2$ for more than six comorbidities, 7,01 for six to nine number of medications, 5 for dependency, 0,7 for one to three episodes of infection, 0,5 for falls, 1,3 for fracture, 3,1 for mental score of less than 18, 1,9 for hemoglobin less than $12 \mathrm{gr} / \mathrm{dl}, 4,03$ for creatinine higher than $1.5 \mathrm{mg} / \mathrm{dl}, 2,43$ for glucose greater than $126 \mathrm{mg} / \mathrm{dl}, 4,8$ for albumin less than $3 \mathrm{~g} / \mathrm{dl}(95 \% \mathrm{Cl})$. Conclusion: The risk factors causing mortality are; old age, BMI less than 20 , more than six comorbidities, more than six medications, dependency, one to three episodes of infection, impaired mental score less than 18, anemia, hyperglycemia, kidney failure, hypoalbuminemia at the patients who admitted to nursing homes. Early optimal monitoring of these parameters can provide a positive contribution to the survival of elderly residents in nursing homes.

Key words: Nursing home; Mortality; Risk factors; Elderly patients
Access this article online

Website:

http://nepjol.info/index.php/AJMS

DOI: 10.3126/ajms.v10i6.25702

E-ISSN: 2091-0576

P-ISSN: 2467-9100

\section{INTRODUCTION}

In developed countries and our country, the ratio of the elderly to the total population is increasing due to the rise in worldwide medical care spendings and the medical workforce allocated for the treatment of the acute and chronic problems of the elderly.
Therefore, knowing the negative risk factors, which are affecting the health status of the elderly directly or indirectly, will help the health care staff to provide optimal follow-up standards as well as more realistic health policies aimed towards this population.

A significant number of people over the age of sixty-five, carry out their daily activities independently; others have

Address for Correspondence:

Dr. Arzu Yalcin, Assistant Professor, Department of Internal Medicine, Yeditepe University, Istanbul İçerenköy mah. Hastahane sok.

No: 4,4/1 Ataşehir/İstanbul, Turkey. Phone Number: +905323669766. E-mail: arzu.yalcin@yeditepe.edu.tr (C) Copyright AJMS 
children and/or other family members or a caregiver living with them in a home environment, while others are forced to live in public or institutional care centers because of financial reasons, desolation, increased dependency, and inability for physical self-maintenance.

The necessity for institutional care centers in our country is increasing every day. In the last ten years, the capacity of these institutions has increased by $400 \%$ and has reached a 25,000-bed volume.

In nursing homes, cross-sectional studies are more likely to be conducted. Demographic characteristics, as well as baseline characteristics, are evaluated in these studies. Longterm survival studies based on observation of risk factors that affect the mortality rates are very few. Such studies are not done frequently in this country. Some small-scale and short-term follow-up studies show that advanced age, ${ }^{1}$ gender, ${ }^{1}$ low body mass index $(\mathrm{BMI})^{2}$, anemia, ${ }^{3,4}$ albumin levels, ${ }^{5}$ kidney failure, ${ }^{3,6}$ low mental score, ${ }^{7-9}$ strenuous activities of daily living (ADL), dependence ${ }^{10}$ and frailty ${ }^{8}$ affect mortality rates negatively while other studies indicate that factors such as anemia, ${ }^{11}$ albumin levels, ${ }^{2,12}$ renal failure ${ }^{11}$ are not associated with high mortality rates. Knowledge is sparse on the factors that affect the mortality of nursing home residents. The survival span of these elders has been shortening due to more restrictive admission criteria. As there are varying opinions on this subject, long-term follow-up studies are still needed.

To determine the risk factors affecting the rate of mortality, we planned a prospective long-term study in a private nursing home with a 150-bed capacity located in Istanbul.

\section{MATERIALS AND METHODS}

The study was an eight-year long term observation of elderly patients selected by the Department of Internal Medicine at the Yeditepe University School of Medicine. Institutional Review Board has reviewed and approved the protocol. The authors have conducted all aspects of the research in this project under the principles of the Declaration of Helsinki.

The study has been carried out in Istanbul between January 2007- January 2015, in a private nursing home with a 150bed capacity.

\section{Study subjects}

\section{Inclusion criteria}

We included all patients over the age of 65 on January $1^{\text {st }}$, 2007 in this study. All subjects were living in a nursing home for over a month. The same internal medicine physicians, neurologists, and psychiatrists followed the patients. In cases of medical and surgical emergencies, we transferred the patients to various hospitals in the region.

\section{Exclusion criteria}

We excluded the patients under the age of 65 or less than one month follow-up period in a nursing home and also the patients who did not give consent for the analysis.

\section{Data collection}

The nursing home documented a detailed medical history of the patients within the first three days of their admission by recording their age, gender, weight, physical examination results, the number and type of medications used, concomitant diseases (hypertension, diabetes, arthritis, heart failure, dementia, renal failure), nutritional status, ADL, MMS score, and baseline laboratory results (complete blood count, levels of albumin, creatinine, glucose).

An internal medicine specialist, neurologist, and a psychiatrist examined the patients. Meanwhile, a psychologist conducted the MMT assessment. Daily care and treatments of the patients were performed by nurses and health care staff. Visits were conducted by an internal medicine specialist every week.

Any interventions needed in acute and chronic conditions were performed on site, while we transferred the patients in need of further assistance to hospitals.

With an interval of 3-6 months, we reevaluated the parameters and medical records and repeated the physical examinations of the patients. We updated the records in case of any deaths in the hospital or nursing home.

Anthropometric measurements: Body weight and height were carefully measured, respectively, to $0.1 \mathrm{~kg}$ and $0.1 \mathrm{~cm}$ accuracy; BMI was calculated in $(\mathrm{kg} / \mathrm{m} 2)$.

We performed MMT to evaluate cognitive function. ${ }^{13}$ Cognitive impairment was measured on a scale of 30 points; 18 and under as severe, $19-23$ as moderate, 24 and above as standard. To evaluate ADL, we used Katz and Stroud's scale. Bathing, getting dressed, eating, walking, and toilet activities were evaluated. We assigned each activity points between 0 and 2; 0: dependent activity, 1: semidependent activity, 2: independent activity. Body weight was evaluated in BMI to define nutritional status. Exton Smith scale was used to evaluate the risk of pressure ulcer.

Intervals: First time interval: 3-6 months; second time interval: 6-12 months; third time interval: $12-18$ months; fourth time interval: 18-24 months; fifth time interval: 24-36 months. 


\section{Statistical analysis}

The data collected were analyzed by using the SPSS 21.0 (Statistical Packages of Social Sciences) program. We assessed the compatibility of the normal distribution of data by Kolmogorov-Smirnov test. Descriptive statistics for continuous variables were shown as mean \pm standard deviation while frequencies and percentages were used to show the categorical variables. Two independent sample t-tests were used to compare the standard distribution data of two independent groups. We performed the Chi-Square analysis test to see the difference between the categorical variables. Using the log-rank test effects of the universe on survival was analyzed. To measure the effects of risk factors on patient survival, we used the hazard ratio and $95 \%$ confidence intervals and values below $\mathrm{p}<0.075$ were considered to be statistically significant. Finally, an eight-year survival curve was created using the Kaplan Meier method.

\section{RESULTS}

During this period 720 of the elderly patients had been accepted into the nursing home where only 612 were eligible for the study. During the eight years, 240 (39\%) patients died, $372(61 \%)$ survived. There is no difference in sex distribution between the groups ( $p$ 0.63). The mean age of the deceased group was $80.40 \pm 10.54$ years while the average age of the living was $73.97 \pm 11.17$ years $(\mathrm{P}<0.00)$. Results related to the deceased and the living are respectively: BMI $22.64 \pm 5.33$ vs. $24.21 \pm 4.95$ (p 0.000), BMI $<20 \mathrm{~kg} / \mathrm{m} 2,33 \%$ vs. $23 \%$ (p 0.017), more than six illnesses in $27 \%$ of the deceased and $8 \%$ of the living (p 0.000). The subjects suffering from cancer, represent $18 \%$ of the deceased and $5 \%$ of the living patients ( $p 0.000$ ). 14\% of the deceased and $3 \%$ in the living patient group use more than eight medications ( $p$ 0.000). Those completely dependent regarding ADL were 20\% in the deceased group and $9 \%$ of the living ( $p 0.000)$. The average MMT score was $14.98 \pm 6.8$ in the deceased group and $18.54 \pm 5.67$ for the living ( $p$ 0.000). Table 1 shows baseline demographic characteristics based on survival of the elderly living in nursing homes.

Laboratory values of the deceased and living groups are; hemoglobin $>12 \mathrm{~g} / \mathrm{dl} 32 \%$ vs $45 \%$ (p 0.026), albumin $<3.0 \mathrm{~g} / \mathrm{dl}$, $36 \%$ vs. $16 \%$ (p 0.000), creatinine $>0.9 \mathrm{mg} / \mathrm{dl}, 67 \%$ vs $49 \%$ (p 0.000$)$, glucose $>126 \mathrm{mg} / \mathrm{dl}, 26 \%$ vs $15 \%$ (p 0.002 ) according to the table. Table 2 shows baseline assessments of the laboratory values of the deceased and living elderly.

Concomitant diseases in the deceased and the living groups were observed as dementia, 48\% and 51\% (p 0.000), malnutrition, 54\% and 45\% (p 0.000), pressure sores, $63 \%$ and $36 \%$ (p 0.000), heart failure, $57 \%$ and

\begin{tabular}{|c|c|c|c|c|}
\hline & General population & Deceased elderly & Living elderly & $P$ value \\
\hline Number & 612 & $240(\% 39,2)$ & $372(\% 60,8)$ & \\
\hline Sex, Female n, \% & $360(\% 58)$ & $144(\% 40)$ & $216(\% 60)$ & 0,635 \\
\hline Weight kg $\pm S D$ & $61,67 \pm 12,24$ & $58,91 \pm 12,83$ & $63,45 \pm 11,52$ & 0,000 \\
\hline $\mathrm{BMI} \pm \mathrm{SD}\left(\mathrm{kg} / \mathrm{m}^{2}\right)$ & $23,59 \pm 5,16$ & $22,64 \pm 5,33$ & $24,21 \pm 4,95$ & 0,000 \\
\hline $20-24.9 \mathrm{~kg} / \mathrm{m}^{2}, \mathrm{n} \%$ & $230(\% 38,1)$ & $91(\% 38,1)$ & $139(\% 38,1)$ & \\
\hline $25-29.9 \mathrm{~kg} / \mathrm{m}^{2}, \mathrm{n} \%$ & $141(\% 23,3)$ & $43(\% 18,0)$ & $98(\% 26,8)$ & \\
\hline$>=30 \mathrm{~kg} / \mathrm{m}^{2}, \mathrm{n} \%$ & $67(\% 11,1)$ & $25(\% 10,5)$ & $42(\% 11,5)$ & \\
\hline Number of diseases, $n \pm S D$ & $4,67 \pm 1,7$ & $5,37 \pm 1,76$ & $4,23 \pm 1,5$ & 0,000 \\
\hline $1-3, n \%$ & $154(\% 25,6)$ & $26(\% 11,2)$ & $128(\% 34,6)$ & 0,000 \\
\hline $4-6, n \%$ & $353(\% 58,6)$ & $143(\% 61,6)$ & $210(\% 56,8)$ & \\
\hline$>6, \mathrm{n} \%$ & $95(\% 15,8)$ & $63(\% 27,2)$ & $32(\% 8,6)$ & \\
\hline \multicolumn{5}{|l|}{ Cancer $n, \%$} \\
\hline Existing $n, \%$ & $65(\% 10,6)$ & $44(\% 18,3)$ & $21(\% 5,6)$ & \\
\hline Number of Medication $\pm S D$ & $5,34 \pm 2,17$ & $6,04 \pm 2,34$ & $4,9 \pm 1,94$ & 0,000 \\
\hline $1-3, n \%$ & $116(\% 19,1)$ & $25(\% 10,5)$ & $91(\% 24,6)$ & 0,000 \\
\hline $4-8, n \%$ & $446(\% 73,5)$ & $179(\% 75,5)$ & $267(\% 72,2)$ & \\
\hline$>8 . \mathrm{n} \%$ & $45(\% 7,4)$ & $33(\% 13,9)$ & $17(\% 3,2)$ & \\
\hline \multicolumn{5}{|l|}{ ADL, Dependency } \\
\hline None, $\mathrm{n} \%$ & 141(\%23) & $31(\% 12,9)$ & $110(\% 29,6)$ & 0,000 \\
\hline Semi, n \% & $389(\% 63,8)$ & $161(\% 67,1)$ & $228(\% 61,3)$ & \\
\hline Complete, n \% & $82(\% 13,4)$ & $48(\% 20)$ & $34(\% 9,1)$ & \\
\hline MMT score $\pm S D(0-30)$ & $17,28 \pm 6,32$ & $14,98 \pm 6,8$ & $18,54 \pm 5,67$ & 0,000 \\
\hline$\leq 18 \mathrm{n}, \%$ & $226(\% 54,5)$ & $110(\% 75,3)$ & $116(\% 43,1)$ & 0.000 \\
\hline $19-23$ n,\% & $129(\% 31,1)$ & $24(\% 16,4)$ & $105(\% 39)$ & \\
\hline$\geq 24 n, \%$ & $60(\% 14,5)$ & $12(\% 8,2)$ & $48(\% 17,8)$ & \\
\hline
\end{tabular}


42\% (p 0.000), COPD, 45\% and 54\%, (p 0.216), paralysis $43 \%$ and $56 \%$ (p 0.265), diabetes, $36 \%$ and $63 \%$ (p 0.41 ), hypertension, $40 \%$ and $59 \%$ (p 0.348), kidney failure $52 \%$ and $48 \%$ ( $p$ 0.013) respectively. Baseline comorbidities of the elderly at their admission to the nursing home are shown in Table 3.

The mean follow-up period in the overall population was $18.6 \pm 23.5$ months, whereas the mean follow-up period in the deceased group was $14.3 \pm 17.5$ months and that in the living group was $21.4 \pm 26.4$ months ( $p$ $=0.000)$. The follow-up period less than one year was $63 \%$ among the deceased and 58\% among the living group, respectively ( $\mathrm{p}$ 0.004). A follow-up rate of more than five years is $4 \%$ in the deceased and $12 \%$ in the living group ( $p$ 0.004).

The percentages for the presence of infection in the followup period were as follows: In the deceased; no infection present: $2 \%$; 1-3 episodes of infection: $91 \%$ ( $p$ 0.000), and in the living; no infection present: $37 \% ; 1-3$ infection episodes: $57 \%$.

Fall rates are $27.9 \%$ in the deceased and $27.6 \%$ in the living ( $p$ 0.697), and the rate of fractures due to those falls are
$13 \%$ and $11 \%$ (p 0.188), respectively. Table 4 shows some of the variables observed during the follow-up.

There is a statistically significant progressive decrease in the number of medications used, noted at six months intervals. The decrease is noted $-2.810(\mathrm{P}<0.05)$ between the first and second time intervals and $-4.766(\mathrm{P}<0.00)$ between first and third time intervals. The living group used more medications during the third time interval (P 0.021) (Graphic 1a).

Some diseases show a decrease (p 0,0019) in all study groups as time intervals progress. In the third time slot, there is a decrease ( $\mathrm{P} \mathrm{0.027)}$ in the number of diseases for the living group (Graphic 1b). The body weight increases progressively in all the groups. The weight difference between the first and fourth time intervals (0.014) and second and fourth intervals (0.042) are statistically significant. Increase in weight is noted in the living group while there is a decrease in the deceased in all time intervals (Graphic 1c). MMT scores progressively decrease in all the groups. The values of the $4^{\text {th }}$ time interval are lower than those in other values ( $p$ 0.000). The changes in MMT scores over time do not show a statistically significant difference between the deceased and the living groups ( $\mathrm{p}>0.05)$. (Graphic $1 \mathrm{~d})$. The

\begin{tabular}{|c|c|c|c|c|}
\hline & General population & Deceased elderly & Living elderly & $P$ value \\
\hline Total & 612 & $240(\% 39,2)$ & $372(\% 60,8)$ & \\
\hline Hemoglobin gr/dl, \pm SD & $11,75 \pm 1,72$ & $11,47 \pm 1,68$ & $11,95 \pm 1,72$ & 0,004 \\
\hline$<9 \mathrm{gr} / \mathrm{dl}, \mathrm{n} \%$ & $34(\% 7,4)$ & $17(\% 9,1)$ & $17(\% 6,2)$ & 0,026 \\
\hline 9-12 gr/dl, n \% & $242(\% 52,6)$ & $109(\% 58,3)$ & $133(\% 48,7)$ & \\
\hline$>12 \mathrm{gr} / \mathrm{dl}, \mathrm{n} \%$ & $184(\% 40)$ & $61(\% 32,6)$ & $123(\% 45,1)$ & \\
\hline Albumin gr/dl $\pm S D$ & $3,51 \pm 0,53$ & $3,37 \pm 0,56$ & $3,61 \pm 0,49$ & 0,000 \\
\hline$<3 \mathrm{gr} / \mathrm{dl} \mathrm{n} \%$ & $82(\% 24,5)$ & $50(\% 36)$ & $32(\% 16,3)$ & 0,000 \\
\hline $3.0-3.5 \mathrm{gr} / \mathrm{dl} n \%$ & $87(\% 26)$ & $37(\% 26,6)$ & $50(\% 25,5)$ & \\
\hline$>3.5 \mathrm{gr} / \mathrm{dl} \mathrm{n} \%$ & $166(\% 49,6)$ & $52(\% 37,4)$ & $114(\% 58,2)$ & \\
\hline Creatinine $\mathrm{mg} / \mathrm{dl} \pm \mathrm{SD}$ & $1,08 \pm 0,49$ & $1,20 \pm 0,58$ & $0,99 \pm 0,39$ & 0,000 \\
\hline$<0.9 \mathrm{mg} / \mathrm{dl}, \mathrm{n} \%$ & $191(\% 43,6)$ & $57(\% 32,4)$ & $134(\% 51,1)$ & 0,000 \\
\hline $0.9-1.5 \mathrm{mg} / \mathrm{dl}, \mathrm{n} \%$ & $210(\% 47,9)$ & $97(\% 55,1)$ & $113(\% 43,1)$ & \\
\hline$>1.5 \mathrm{mg} / \mathrm{dl}, \mathrm{n} \%$ & $37(\% 8,4)$ & $22(\% 12,5)$ & $15(\% 5,7)$ & \\
\hline Glucose $\mathrm{mg} / \mathrm{dl} \pm \mathrm{SD}$ & $112,8 \pm 42,89$ & $120,13 \pm 46,49$ & $108,51 \pm 40,11$ & 0,006 \\
\hline$<110 \mathrm{mg} / \mathrm{dl} \mathrm{n} \mathrm{\%}$ & $297(\% 68,1)$ & $93(\% 57,8)$ & $204(\% 74,2)$ & 0,002 \\
\hline $110-126 \mathrm{mg} / \mathrm{dl}$ n. $\%$ & $55(\% 12,6)$ & $26(\% 16,1)$ & $29(\% 10,3)$ & \\
\hline$>126 \mathrm{mg} / \mathrm{dl} \mathrm{n} \%$ & $84(\% 9,3)$ & $42(\% 26,1)$ & $42(\% 15,3)$ & \\
\hline
\end{tabular}

\section{Table 3: Baseline assesment of comoborbidity characteristics in the living and the deceased elderly}

\begin{tabular}{|c|c|c|c|c|}
\hline & General population & Deceased elderly & Living elderly & $P$ value \\
\hline Total & 612 & $372(\% 39,2)$ & $240(\% 60,8)$ & \\
\hline Dementia, n \% & $256(\% 41)$ & $124(\% 48,4)$ & $132(\% 51,6)$ & 0,000 \\
\hline Malnutrition, $\mathrm{n} \%$ & $222(\% 36)$ & $120(\% 54,1)$ & $102(\% 45,9)$ & 0,000 \\
\hline Pressure sores, $\mathrm{n} \%$ & $66(\% 10.7)$ & $42(\% 63,6)$ & $24(\% 36,4)$ & 0,000 \\
\hline Heart Failure, $\mathrm{n} \%$ & $121(\% 19.7)$ & $70(\% 57,9)$ & $51(\% 42,1)$ & 0,000 \\
\hline COPD, n \% & $91(\% 14)$ & $41(\% 45,1)$ & $50(\% 54,9)$ & 0,216 \\
\hline Stroke, $\mathrm{n} \%$ & $119(\%(\% 19,4)$ & $52(\% 43,7)$ & $67(\% 56,3)$ & 0,265 \\
\hline Hypertension, n \% & $389(\% 60)$ & $158(\% 40,6)$ & $231(\% 59,4)$ & 0,348 \\
\hline Kidney Failure, n \% & $88(\% 14.3)$ & $45(\% 51,1)$ & $43(\% 48,9)$ & 0,013 \\
\hline
\end{tabular}




\begin{tabular}{|c|c|c|c|c|}
\hline & General population & Deceased elderly & Living elderly & $P$ value \\
\hline Total & 612 & $372(\% 39,2)$ & $240(\% 60,8)$ & \\
\hline Follow up period, ay $\pm S D$ & $18,66 \pm 23,58$ & $14,30 \pm 17,53$ & $21,48 \pm 26,42$ & 0,000 \\
\hline$<=12$ ay $(\mathrm{n} ; \%)$ & $369(\% 60,3)$ & $153(\% 63,8)$ & $216(\% 58,1)$ & 0,004 \\
\hline $13-24$ ay $(n ; \%)$ & $86(\% 14,1)$ & $42(\% 17,5)$ & $44(\% 11,8)$ & \\
\hline $25-36$ ay $(n ; \%)$ & $43 / \% 7,0)$ & $19(\% 7,9)$ & $24(\% 6,5)$ & \\
\hline $37-48$ ay $(n ; \%)$ & $35(\% 5,7)$ & $10(\% 4,2)$ & $25(\% 6,7)$ & \\
\hline $49-60$ ay $(n ; \%)$ & $24(\% 3,9)$ & $6(\% 2,5)$ & $18(\% 4,8)$ & \\
\hline$>60$ ay $(\mathrm{n} ; \%)$ & $55(\% 9,0)$ & $10(\% 4,2)$ & $45(\% 12,1)$ & \\
\hline Number of Infections, $n \pm S D$ & $1,7 \pm 1,15$ & $1,75 \pm 1,21$ & $1,66 \pm 1,10$ & 0,215 \\
\hline No Episodes, n \% & $142(\% 25,5)$ & $4(\% 2,2)$ & $138(\% 37,1)$ & 0,000 \\
\hline $1-3$ episodes , $n \%$ & $382(\% 68,7)$ & $168(\% 91,3)$ & $214(\% 57,5)$ & \\
\hline$>3$ episodes, $n \%$ & $32(\% 5,8)$ & $12(\% 6,5)$ & $20(\% 5,4)$ & \\
\hline \multicolumn{5}{|l|}{ Falls } \\
\hline No Falls , n \% & $442(\% 72,2)$ & $173(\% 72)$ & $269(\% 72,3)$ & 0,697 \\
\hline Fall $1, \mathrm{n} \%$ & $156(\% 25,5)$ & $60(\% 25)$ & $96(\% 25,8)$ & \\
\hline Falls $>1, n \%$ & $14(\% 2,3)$ & $7(\% 2,9)$ & $7(\% 1,8)$ & \\
\hline \multicolumn{5}{|l|}{ Fractures } \\
\hline Non-existent , n \% & $538(\% 87,9)$ & $207(\% 86,2)$ & $331(\% 89)$ & 0,188 \\
\hline Existing , $\mathrm{n} \%$ & $74(\% 12,1)$ & $33(\% 13,8)$ & $41(\% 11)$ & \\
\hline
\end{tabular}

Table 5: 8-year follow-up of risk ratios for all causes of mortality

\begin{tabular}{|c|c|c|c|c|c|c|c|}
\hline Characteristics & Hazard Ratio & $\% 95 \mathrm{Cl}$ & $P$ value & Characteristics & Hazard Ratio & $\% 95 \mathrm{Cl}$ & $P$ value \\
\hline Age, year & 1,311 & $1,019-1,042$ & 0,000 & \multicolumn{2}{|c|}{ Mini Mental Test Score (0-30) } & & \\
\hline Women, sex & 1,022 & $0,789-1,323$ & 0,869 & $\leq 18$ & 3,170 & $1,743-5,768$ & 0,000 \\
\hline Weight, kg & 0,980 & $0,969-0,991$ & 0,000 & $19-23$ & 1,315 & $0,657-2,634$ & 0,439 \\
\hline BMI (kg/m2) & & & & $\geq 24$ & Reference & & \\
\hline$<20 \mathrm{~kg} / \mathrm{m} 2$ & 1,519 & $1,124-2,053$ & 0,007 & Hemoglobin gr/dl & & & \\
\hline $20-24.9 \mathrm{~kg} / \mathrm{m} 2$ & Reference & & & $<9 \mathrm{gr} / \mathrm{dl}$ & 1,445 & $0,760-2,747$ & 0,261 \\
\hline $25-29.9 \mathrm{~kg} / \mathrm{m} 2$ & 0,863 & $0,606-1,229$ & 0,414 & $9-12 \mathrm{gr} / \mathrm{dl}$ & 1,949 & $1,424-2,667$ & 0,000 \\
\hline$>=30 \mathrm{~kg} / \mathrm{m} 2$ & 0,791 & $0,496-1,259$ & 0,327 & $>12 \mathrm{gr} / \mathrm{dl}$ & Referens & & \\
\hline \multicolumn{2}{|c|}{ Number of Patients, $n$} & & & Albumin gr/dl & & & \\
\hline $1-3$ & Reference & & & $<3 \mathrm{gr} / \mathrm{dl}$ & 4,894 & $2,889-8,290$ & 0,000 \\
\hline $4-6$ & 2,615 & $1,721-3,974$ & 0,000 & $3.0-3.5 \mathrm{gr} / \mathrm{dl}$ & 2,631 & $1,821-3,803$ & 0,000 \\
\hline$>6$ & 4,279 & $2,704-6,771$ & 0,000 & $>3.5 \mathrm{gr} / \mathrm{dl}$ & Reference & & \\
\hline \multicolumn{2}{|c|}{ Number of Medication use } & & & Creatinine $\mathrm{mg} / \mathrm{dl}$ & & & \\
\hline $1-3$ & Reference & & & $<0.9 \mathrm{mg} / \mathrm{dl}$ & Reference & & \\
\hline $3-6$ & 4,404 & $1,623-11,947$ & 0,004 & $0.9-1.5 \mathrm{mg} / \mathrm{dl}$ & 2,788 & $1,914-4,062$ & 0,000 \\
\hline $6-9$ & 7,007 & $2,577-19,053$ & 0,000 & $>1.5 \mathrm{mg} / \mathrm{dl}$ & 4,033 & $2,368-6,867$ & 0,000 \\
\hline$>=10$ & 10,610 & $3,561-31,617$ & 0,000 & & & & \\
\hline \multicolumn{2}{|l|}{ ADL Dependency } & & & Glucose mg/dl & & & \\
\hline None & referens & & & $<110 \mathrm{mg} / \mathrm{dl}$ & Reference & & \\
\hline Partial & 3,023 & $2,052-4,545$ & 0,000 & $110-126 \mathrm{mg} / \mathrm{dl}$ & 2,192 & $1,522-3,159$ & 0,000 \\
\hline Complete & 5,246 & $3,325-8,275$ & 0,000 & $>126 \mathrm{mg} / \mathrm{dl}$ & 2,431 & $1,652-3,577$ & 0,000 \\
\hline \multicolumn{2}{|c|}{ Number of Infections } & & & & & & \\
\hline No episodes & Reference & & & Malnutrition, & 1,947 & $1,511-2,509$ & 0,000 \\
\hline 1-3 episodes & 0,718 & $0,530-0,973$ & 0,033 & Pressure sore & 1,948 & $1,396-2,720$ & 0,000 \\
\hline$>3$ episodes & 0,289 & $0,153-0,546$ & 0,000 & Heart Failure & 1,871 & $1,416-2,472$ & 0,000 \\
\hline \multicolumn{2}{|l|}{ Falls } & & & COPD & 1,149 & $0,821-1,609$ & 0,417 \\
\hline None & Reference & & & Stroke & 1,421 & $1,044-1,933$ & 0,026 \\
\hline Existing Falls & 0,536 & $0,400-0,179$ & 0,000 & Diabetes & 0,952 & $0,708-1,282$ & 0,747 \\
\hline Falls $>3$ & 1,157 & $0,369-3,628$ & 0,802 & Hypertension & 1,183 & $0,906-1,545$ & 0,218 \\
\hline \multicolumn{2}{|l|}{ Fracture } & & & Kidney failure & 1,32 & $0,957-1,831$ & 0,09 \\
\hline $\begin{array}{l}\text { Existing } \\
\text { None }\end{array}$ & $\begin{array}{c}1,351 \\
\text { Reference }\end{array}$ & $0,935-1,952$ & 0,109 & Dementia & 1,306 & $1,014-1,683$ & 0,039 \\
\hline
\end{tabular}

creatinine level progressively increases in all of the groups over time. There is a statistically significant difference between the first and second time intervals and first and third time intervals ( $\mathrm{p}: 0.019, \mathrm{p} 0.028$ ). There is, however, no statistically significant difference among the values of creatinine levels in the deceased and the living groups (p>0.05) (Graphic 2a).

We did not find statistically significant changes in albumin levels in either group at successive time intervals. The level of 


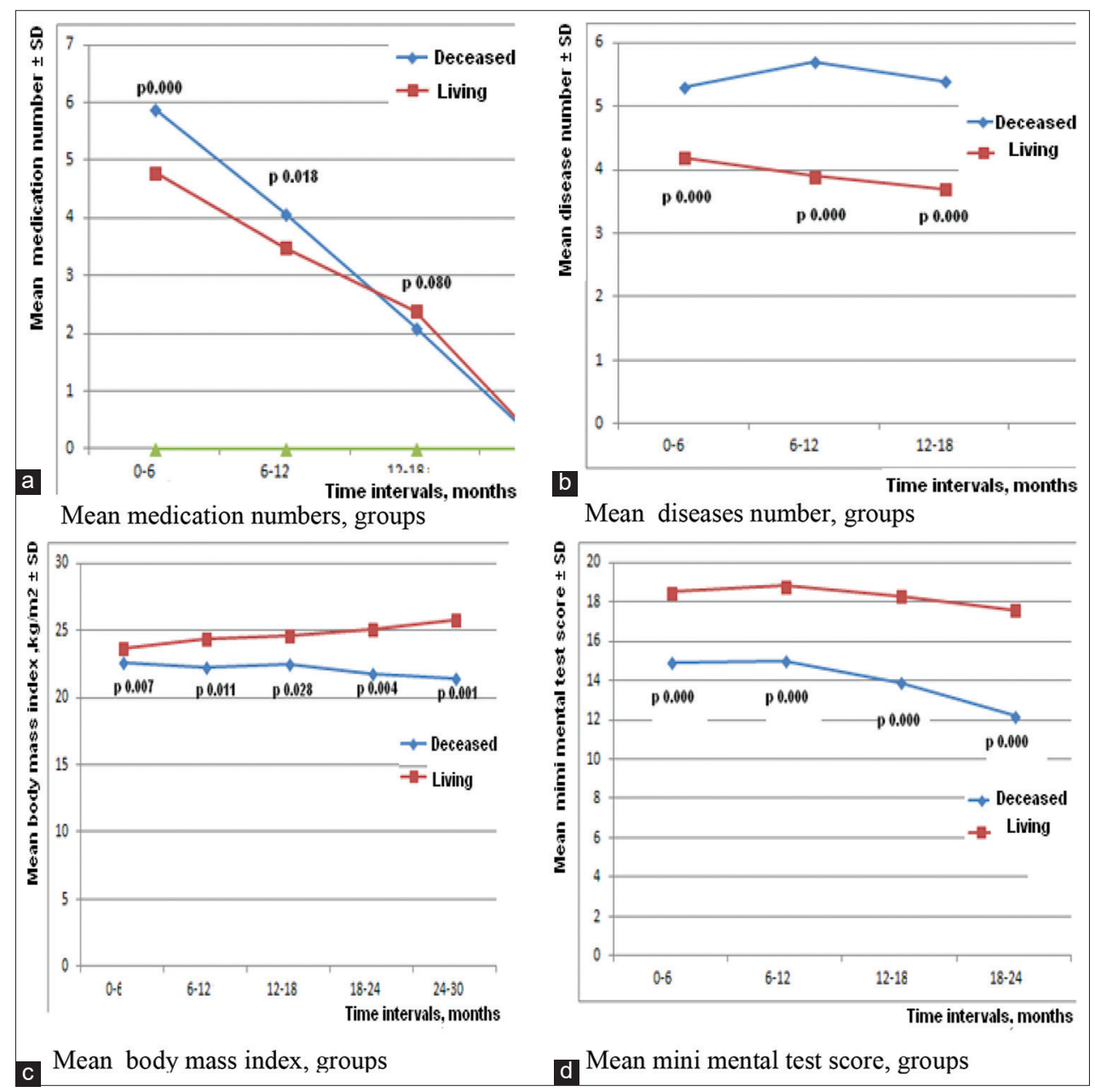

Graphic 1: Number of medication use, BMI and MMT parameters over a course of time in the deceased and living elderly.

albumin has decreased in the deceased group ( $\mathrm{p} 0.015)$ (Graphic $2 \mathrm{~b})$. The average of glucose levels decreased progressively in the whole group ( $p$ 0.012), and the change is statistically significant. There was no statistically significant difference in glucose levels between the groups (Graphic 2c). At consecutive time intervals, changes in hemoglobin levels were not found to be statistically significant in either group. In the deceased group the hemoglobin level has decreased ( $\mathrm{p}$ 0.005), while it has increased in the living group (p 0.011) (Graphic 2d).

Older age, BMI less than 20, more than four comorbidities, use of more than six medications, dependency, more than three infection episodes, falls, MMS less than 18, anemia, hypoalbuminemia, creatinine greater than $0.9 \mathrm{mg} / \mathrm{dl}$, and hyperglycemia are all factors that carry high-risk ratio toward mortality (Table 5).

Graphic 3 shows the cumulative survival curve. The overall median survival time is 34 months. A total of $240(39 \%)$ residents died within eight years, $44 \%$ within two years and $55 \%$ of the residents within three years.

\section{DISCUSSION}

This study showed the median survival time of nursing home residents in Istanbul was 34 months (5.5 years) with a stable death rate over the whole period of the study. Almost $28 \%$ of the residents have died within a year of the admission date; a majority have died within three years, and less than half of the residents lived longer than three years. Out of the 612 elderly included in the study, $60 \%$ were followed-up for less than a year, and 10\% of the patients were followed-up for more than five years. In this follow-up period, the all-cause mortality rate was found to be $40 \%$. We have identified old age, BMI less than 20, more than four comorbidities, more than six medications, high dependency rate, three or more infection episodes, occurrence of falls, MMS less than eight, hemoglobin less than $12 \mathrm{~g}$, albumin less than $3.5 \mathrm{~g} / \mathrm{dl}$, creatinine higher than $1 \mathrm{mg} / \mathrm{dl}$, fasting blood glucose greater than $126 \mathrm{mg} / \mathrm{dl}$ as high-risk factors for mortality.

Gender did not seem to play a significant role in the mortality rate between the deceased and the living groups. Equal care and living conditions for both genders in the

Asian Journal of Medical Sciences | Nov-Dec 2019 | Vol 10 | Issue 6 


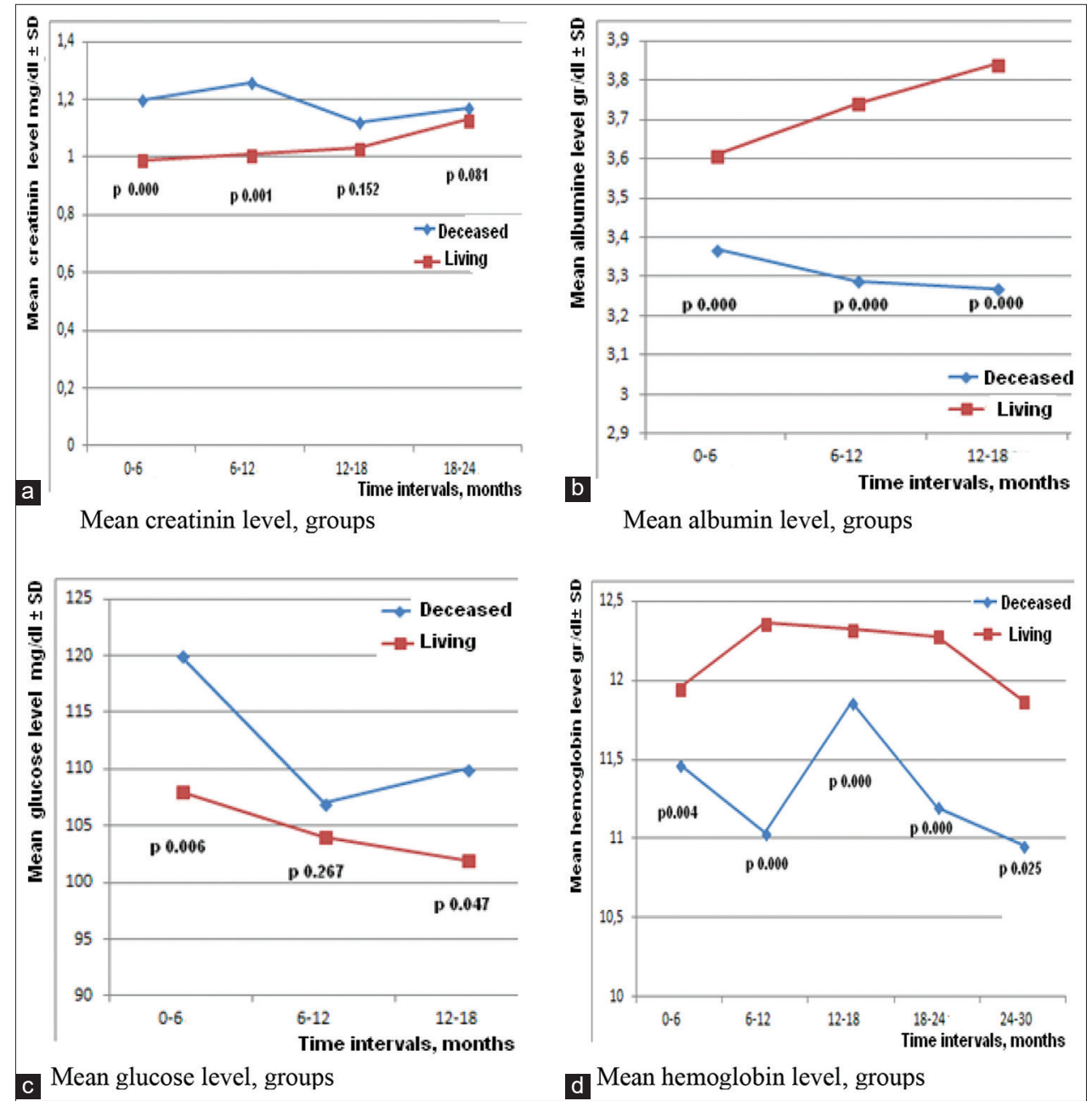

Graphic 2: Creatinine, albumin, glucose, hemoglobin changes in the two groups at progessive time intervals

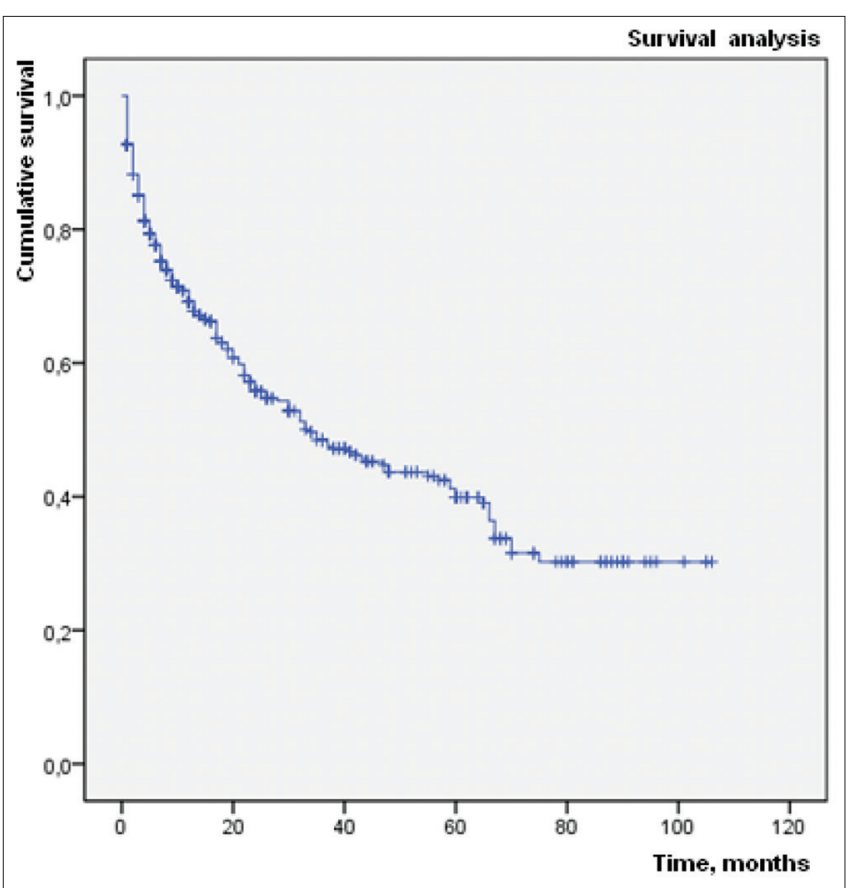

Graphic 3: Cumulative survival curve nursing home may have played a significant role in this. Although there are some studies in Europe and USA showing the male gender as a cause for higher mortality rates among mixed dementia patients in nursing homes, ${ }^{14-16}$ a study in China, however, states that mortality is not linked with either gender or race. ${ }^{17}$

Different elderly care units reported malnutrition at a rate of $12-85 \% .{ }^{18}$ The average weight of the deceased group was $58 \mathrm{~kg}$ while it was $63 \mathrm{~kg}$ in the living group. At the end of the follow-up, these values have declined to $54 \mathrm{~kg}$ in the deceased and gone up to $69 \mathrm{~kg}$ in the living, making this $10 \%$ change statistically significant. The average BMI in the deceased group was $22 \mathrm{~kg} / \mathrm{m} 2$, while it was $23 \mathrm{~kg} / \mathrm{m} 2$ in the living group. At the end of follow-up, BMI has gone down to $21 \mathrm{~kg} / \mathrm{m} 2$ in the deceased and up to $25 \mathrm{~kg} / \mathrm{m} 2$ in the living. The initial rates of BMI under $20 \mathrm{~kg} / \mathrm{m} 2$ was $33 \%$ for the deceased and has declined to $31 \%$ at the end of the follow-up. These rates have gone down to $13 \%$ from $23 \%$ in the living group. Especially early diagnosis and intervention in weight loss in the elderly would be 
an important contribution to survival. In our study, the mean BMI was found to be $23.59 \mathrm{~kg} / \mathrm{m} 2 \pm 5.16$. In Chan's study in 2013, the average BMI was $18.8 \pm 3.5 \mathrm{~kg} / \mathrm{m} 2$ in a similar population, and $52 \%$ of the BMIs were under 18,5 . According to our results, these rates seem quite high. In the same study, BMI less than 18.5 levels have been associated with a three-fold increase in mortality. ${ }^{17}$

Meanwhile, other studies show BMI less than 18.5 as a predictor of mortality. ${ }^{19,20}$ In our study, BMI less than twenty was found to be a 1.5-fold increase in risk. In this country, a large-scale study has shown a $33.5 \%$ malnutrition risk and $13.5 \%$ actual malnutrition in patients residing in nursing homes; ${ }^{21}$ which shows parallel results with our study.

The relationship between morbidity and mortality in elderly individuals with hypertension and other comorbidities are controversial. Studies are indicating no such relation ${ }^{22}$ as well as studies showing an indirect relationship as well. ${ }^{23}$ In our study, the baseline value for having more than six diseases was $27 \%$ in the deceased and $8 \%$ in the living group. Initially, the average comorbidity in the deceased was 5.3 and in the living 4.2 while the rates have increased in the deceased and decreased in the living (5.4 vs. 3.7 ) at the end of the follow-up. The elderly with more than six diseases had a 2.7-fold higher risk of mortality. Cancer is an important cause of mortality in the elderly. Initially, in our study, the cancer rate in the deceased was $18 \%$ while it was $5 \%$ in the living.

The rate of patients initially taking more than four medications was $90 \%$ in the deceased and $75 \%$ in the living while the rate of those taking more than eight medications was $14 \%$ in the deceased and only $3 \%$ in the living group. Initially, the mean number of medications used was six in the deceased and five in the living group. At the end of the study, the number of medications used, stayed the same in the deceased group while average drug use had increased to six in the living. Having the option of palliative care, the number of medications used did not increase in the deceased group since the dependency rate was high in their comprehensive assessment. The Onder's Study 2013, shows $14 \%$ polypharmacy and an increase in mortality risk (HR $2,9) .{ }^{24}$ In our study, polypharmacy was found to be $14 \%$ in the deceased and $4 \%$ in the living group, suggesting a higher mortality risk (HR 10).

Initially, full dependency rate involving ADL such as eating, dressing, toilet use, and walking in the deceased was $20 \%$ while it was $9 \%$ in the living group. However, at the end of the follow-up, these rates were $42 \%$ in both the dead and the living groups. Even with professional care support, after becoming entirely dependent, it is difficult to make the elderly semi-dependent and independent again. At the end of the follow-up period, the rate of the independent elderly was 3\% in the deceased group and $41 \%$ in the living group. The living group had a better chance of rehabilitation as time progressed. In one study, ADL dependency at varying levels in nursing homes were $71 \% 0^{25}$ while in our study, the ratio was $87 \%$ in deceased patients, and $70 \%$ in the living ones.

The rate of severe cognitive dysfunction $(<18)$ was $75 \%$ in the deceased group (mean MMSE 14.9) and 43\% in the living group (mean MMSE 18.5). Matusik's study 2012, of dementia and fragility in the elderly, separately does not show a significant difference in mortality but cognitive dysfunction was associated with mortality when evaluated together. Percentages of patients with severe cognitive dysfunction rate were $55.8 \%$, and the standard mental score rate was $17 \%{ }^{26}$ in the Marusikís study. Our study has similar results with $54 \%$ severe cognitive dysfunction and $15 \%$ average mental score. When evaluated individually, low performance and low scores on mental tests were found to be a risk factor for mortality. Another study reported that the rate of cognitive dysfunction was $67-72 \%$ in nursing homes. $^{27}$

The baseline assessment showed that $\mathrm{Hb}$ levels were under $12 \mathrm{~g} / \mathrm{dl}$ in $60 \%$ of the overall group, $68 \%$ in the deceased and $55 \%$ in the living group. While hemoglobin levels have decreased in the deceased group, these levels have increased in the living group in time. Chronic diseases, nutritional deficiency, malignancy, iron deficiency, vitamin B12 deficiency anemia are the leading causes of anemia in nursing homes. In the Artzs study in 2004, the prevalence of anemia in the nursing home residents was $48 \%,{ }^{28}$ and $40 \%$ in another study. ${ }^{29}$

Deterioration of renal function can be a cause of higher incidence of anemia in the elderly, regardless of age. The incidences of chronic renal failure were $33 \%$ in the ages $65-74,39 \%$ in the ages $75-84$, and $49 \%$ in the ages 85 and above in the Robinsons study in $2007 .{ }^{30}$ In Canada, a study in nursing home residents found CRF rates as $27 \%$ in men and $39 \%$ in women. ${ }^{31}$ In our study, creatinine greater than $0.9 \mathrm{mg} / \mathrm{dl}$ was found to be $67 \%$ in the deceased group and $48 \%$ in the living group. Mortality was 2.3 times higher in those with creatinine over $1.5 \mathrm{mg} / \mathrm{dl}$.

In the baseline assessment, $36 \%$ of the elderly in the deceased group had albumin levels of less than 3 grams, while this value was found in $16 \%$ in the living group. In time, the albumin level also decreased in the deceased group. In the deceased group, the average fasting blood glucose was $120 \mathrm{mg}$ while the ratio of levels above $126 \mathrm{mg}$ was $26 \%$. In the living group, the average fasting blood 
glucose was $108 \mathrm{mg}$, and the ratio above $126 \mathrm{mg}$ was $15 \%$. Later on, however, the fact that the progression of glycemia did not differ between these two groups, can be explained by careful and correct monitoring of glucose levels at the nursing home. In Lubarts study 2013, the diabetic rate was $36 \%$ while, average fasting blood glucose was $144 \mathrm{mg}$. ${ }^{32}$ In our study, $26 \%$ of the total population had diabetes. Presence or absence of diabetes is not a risk factor for mortality, but glycemia above $126 \mathrm{mg}$ is a variance for the 2.5 -fold increase in the risk of mortality.

Ninty one percent of the deceased group experienced 1-3 episodes of infection during the study while this rate was $57 \%$ in the living group. When the Zorman's study in 2013 compared infections in the elderly living in nursing homes and the general population, they described greater mortality rate $(23 \%$ vs. $10 \%)$ and greater functional loss $(23 \%$ vs. $10 \%)$, respectively, in nursing home residents. ${ }^{33}$

During the follow-up period, we did not find a significant difference between falls and fractures. There were cases of falls in the $25 \%$ and fractures in the $12 \%$ of the groups. Schaller's study in 2012, did not find increased two-year mortality risk after a hip fracture as significant. ${ }^{34}$

We found several factors to predict mortality at admission to a nursing home.

\section{REFERENCES}

1. Hjaltadottir I, Hallberg IR, Ekwall AK and Nyberg P. Predicting mortality of residents at admission to nursing home: a longitudinal cohort study. BMC Health Serv Res 2011;11:86.

2. Veronese N, Rui MD, Toffanello ED, Ronch ID, Perissinotto E, Bolzetta $F$, et al. Body mass index as a predictor of all-cause mortality in nursing home residents during a 5-year follow-up. J American Med Dir Assoc 2013;14(1):53-57.

3. Kurella Tamura M, Covinsky KE, Chertow GM, Yaffe K, Landefeld $\mathrm{CS}$ and McCulloch CE. Functional status of elderly adults before and after initiation of dialysis. N Engl J Med 2009;361:15391547.

4. van Dijk PT, Mehr DR, Ooms ME, Madsen R, Petroski G, Frijters $\mathrm{DH}$, et al. Comorbidity and 1-year mortality risks in nursing home residents. J Am Geriatr Soc 2005;53(4):660-665.

5. Corti MC, Guralnik JM, Salive ME, Sorkin JD. Serum albumin level and physical disability as predictors of mortality in older persons. JAMA 1994; 272: 1036-1042.

6. Chan TC, Yap DYH, Shea YS, Luk JKH, Chu LW and Chan FHW. Chronic Kidney Disease and Its Association With Mortality and Hospitalization in Chinese Nursing Home Older Residents: A 3-Year Prospective Cohort Study JAMDA 2012; 13:782-787.

7 Fried LP, Tangen CM, Walston J, Newman AB, Hirsch C, Gottdiener J, et al. Cardiovascular Health Study Collaborative Research Group, Frailty in older adults: Evidence for a Phenotype. The J Gerontol A Biol Sci Med Sci 2001; 56, 146-156.

8. Gallucci M, Ongaro F, Amici GP and Regini C. Frailty, disability and survival in the elderly over the age of seventy: evidence from "The Treviso Longeva (TRELONG) Study." Arch Gerontol
Geriatr 2009; 48:281-283.

9. Bonaiuto S, Mele M, Galluzzo L and Giannandrea E. Survival and dementia: a 7-year follow-up of an Italian elderly population. Arch Gerontol Geriatr 1995; 20:105-113.

10. Chan TC, Shea YF, Luk KH, Chu LW and ChanHW. Association between functional status of Chinese nursing home older adults and long term mortality. J Am Med Dir Assoc 2013; 14: e1- e5.

11. Binder EF, White HK, Resnick B, McClellan WM, Lei $L$ and Ouslander JG. A Prospective Study of Outcomes of Nursing Home Residents with Chronic Kidney Disease with and without Anemia. J Am Geriatr Soc 2012; 60:877-883.

12. Volpato S, Romagnoni F, Soattin L, Ble A, Leoci V, Bollini C, et al. Body mass index, body cell mass, and 4-year all-cause mortality risk in older nursing home residents. J Am Geriatr Soc 2004; 52:886-891.

13. Folstein MF, Folstein SE and McHugh PR. iMini-mental stateî: A practical method for grading the cognitive state of patients for the clinician. Journal of Psychiatric Research 1975; 12: 189-198.

14. Flacker JM and Kiely DK. Mortality-related factors and 1-year survival in nursing home residents. J Am Geriatr Soc 2003; 51:213-221.

15. Porock D, Parker-Oliver D, Petroski GF and Rantz M. The MDS mortality risk index: the evolution of a method for predicting 6 -month mortality in nursing home residents. BMC Res Notes 2010;3:200.

16. Kruse RL, Parker Oliver D, Mehr DR, Petroski GF, Swenson DL and Zweig SC. Using mortality risk scores for long-term prognosis of nursing home residents: caution is recommended. $\mathrm{J}$ Gerontol A Biol Sci Med Sci 2010; 65:1235-1241.

17. Chan M, Lim YP, Ernest $A$ and Tan L. Nutritional assesment in an Asian nursing home and its association with mortality The Journal of Nutrition Health Aging 2010;14(1):23-28.

18. Allard JP, Aghdassi E, McArthur M, Mcgeer A, Simor A, Abdolell $M$, et al. Nutrition risk factors for the survival in elderly living in Canadian long term care facilities. J Am Geriatr Soc 2004:59-65.

19. Flegal KM, Graunbard BI, Williamson DF and Gail MH. Excess deaths associated with underweight, overweight, and obesity. JAMA 2005; 293:1861-1867.

20. Gu D, He J, Duan X, Reynolds K, Wu X, Chen J, et al. Body weight and mortality among men and women in China. JAMA 2006; 295:776-783.

21. Saka B, Akın S, Tufan F, Öztürk GB, Engin S, Karışık E, et al. Huzurevi Sakinlerinin Malnütrisyon Prevalansı ve Sarkopeni ile Illişkisi İç Hastalıkları Dergisi 2012; 19: 39-46.

22. Askari M, Kiely DK and Lipsitz LA. Is pulse pressure a predictor of cardiovascular complications in a frail elderly nursing home population? Aging Clin Exp Res 2004; 16:206-211.

23. Oates DJ, Berlowitz DR, Glickman ME, Silliman RA and Borzecki AM. Blood pressure and survival in the oldest old. J Am Geriatr Soc 2007;55:383-388.

24. Onder G, Liperoti R, Foebel A, Fialova D, Topinkova E, van der Roest HG, et al. SHELTER Project Polypharmacy and mortality among nursing home residents with advanced cognitive impairment: results from the shelter study. J Am Med Dir Assoc 2013;14(6):450.

25. Boorsma M, van Hout HP, Frijters DH, Ribbe MW and Nijpels G. The cost-effectiveness of a new disease management model for frail elderly living in homes for the elderly, design of a cluster randomized controlled clinical trial. BMC Health Serv Res 2008;8:143.

26. Matusik P, Tomaszewski K, Chmielowska K, Nowak J, Nowak W, Parnicka A, et al. Severe frailty and cognitive impairment are 
related to higher mortality in 12-month follow-up of nursing home residents Archives of Gerontology and Geriatrics 2012:55: 22-24.

27. Rovner BW, German PS, Broadhead J, Morriss RK, Brant LJ, Blaustein $\mathrm{J}$, et al. The prevalence and management of dementia and other psychiatric disorders in nursing homes. Int. Psychogeriatr 1990; 2:13-24.

28. Artz AS, Fergusson D, Drinka PJ, Gerald M, Gravenstein S, Lechich A, et al. Prevalence of anemia in skilled-nursing home residents. Arch Gerontol and Geriatr 2004; 39:201-206.

29. Kalchthaler $T$ and Tan ME. Anemia in institutionalized elderly patients. J Am Geriatr Soc 1980; 28:108-113.

30. Robinson B, Artz AS, Culleton B, Critchlow C, Sciarra A and Audhya P. Prevalence of anemia in the nursing home: contribution of chronic kidney disease. J Am Geriatr Soc 2007; 55(10):1566-1570.
31. Garg AX, Papaioannou A, Ferko N, Campbell G, Clarke JA and Ray JG. Estimating the prevalence of renal insufficiency in seniors requiring long-term care. Kidney Int 2004; 65(2):649-653.

32. Lubart E, Segal R, Wainstein J, Marinov G, Yarovoy A and Leibovitz A. Evaluation of an intra-institutional diabetes disease management program for the glycemic control of elderly long-term care diabetic patients. Geriatr and Gerontol Int 2014; 14(2):341-345.

33. Videcnik Zorman J, Lusa L, Strle $F$ and Maraspin V. Bacterial infection in elderly nursing home and community-based patients: a prospective cohort study. Infection 2013; 909-916.

34. Schaller F, Sidelnikov E, Theiler R, Egli A, Staehelin HB, Dick W, et al. Mild to moderate cognitive impairment is a major risk factor for mortality and nursing home admission in the first year after hip fracture Bone 2012;51(3): 347-352.

\section{Authors Contribution:}

YK, YA and MHT- Concept and design of the study, reviewed the literature, manuscript preparation and critical revision of the manuscript; YK, MAO and BK- Concept, collected data and review of literature and helped in preparing first draft of manuscript; YK and ECA- Conceptualized study, literature search, statistically analyzed and interpreted, prepared first draft of manuscript and critical revision of the manuscript; YK, AY MHT- Concept of study, collected data and review of study.

\section{Work attributed to:}

Department of Internal Medicine, Yeditepe Kozyatagı Hospital, Atasehir, Istanbul.

Orcid ID:

Dr. Yasar Kucukardali - (iD http://orcid.org/0000-0002-8719-8886

Dr. Arzu Yalcin - (D http://orcid.org/0000-0002-1941-8699

Dr. Murat Hakan Terekeci - (D) http://orcid.org/0000-0003-2045-1709

Dr. Mehmet Akif Ozturk - (i) http://orcid.org/0000-0003-1096-7306

Dr. Betul Kucukardali - (1) http://orcid.org/0000-0002-7320-0308

Dr. Elif C.Altunok - (D) http://orcid.org/0000-0002-2479-1236 